\title{
Individual Trajectory of Professional Growth of a Teacher in Russia
}

\author{
Svetlana Dovbysh ${ }^{1, a}$, Maxim Bakhtin ${ }^{1, b}$, Anna Arinushkina ${ }^{1, c *}$ \\ 1 Institute of Education Management of the Russian Academy of Education, 105062, 16 \\ Zhukovskogo str., Moscow, Russia

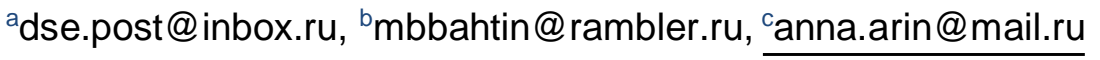 \\ ${ }^{*}$ Corresponding author
}

\begin{abstract}
Keywords: postmodernist paradigm, the content of education, teacher's professional activities, forms and means of education, role, teacher, professional performance assessment system, professional standard, national systems of professional growth for teachers
\end{abstract}

\begin{abstract}
The postmodern paradigm significantly affects the nature of social change, including in the field of education. This is reflected in the content of education, in the content of the teacher's professional activity, in the forms and means of education. In this regard, the role of a teacher in the modern world cannot but change, the field of professional activity and responsibility of a teacher becomes wider. New approaches to the system of professional assessment and professional growth of teachers are being modified and developed, which are fixed in the professional standard and the national system of professional growth of teachers.
\end{abstract}

\section{Introduction}

In social science, they were born and quickly took the leading position of the paradigm, being combined with the signs of the new time. They are influenced by the factors of globalization, virtualization, and 'networking" of information, communication and cultural spaces. In the center of modern scientific pedagogical research and in today's fast-changing reality, there are not static objects and knowledge about them but dynamic processes, in particular: the correlation of knowledge about an object not only with tools and operations, but also with value-oriented activity structures. As a result, the subjectivity of knowledge, consideration of probabilistic, conditional, multidisciplinary, variations of model knowledge are observed. These phenomena correlate with the conceptual characteristics of postmodernism, which can be described as a special way of reflecting the main trends and guidelines of a society that has reached a certain level of development.

\section{Methodology}

The article actualizes the problems of the system of additional professional education of teachers in the context of the transformation of the modern world, new approaches to the system of evaluation of professional activity and to the professional growth of teachers. The key problem in the system of additional professional education of teachers is the lack of modern didactic teaching aids, which make it possible to build an individual trajectory of professional growth in a changing social and educational situation.

\section{Research}

A system of additional professional education for teachers (APET) was and is the subject of attention of many Russian and foreign researchers.

The actual problems of raising the qualifications of teachers are covered in the works by Van der Heijden [1], Kelly, J., Cherkowski, S. [2], Kleickmann, T. [3], Johnson, K. E., Golombek, P. R [4], and others. A study on a number of works by Russian researchers shows that the modern APET system of teachers in Russia has evolved from the system of teacher improvement to the system of professional growth of teachers and is currently in a situation of changes in response to the challenges of modern socioeducational reality (Klarin, M.V. [5], Logvinova, I. M. [6], Zmeyov, S. I. [7], Nevzorov, M. N. [8], Neustroev, S. S. et al. [9]). According to the authors, the main strategy in building content, its management, and implementation becomes the refusal of the training approach, the essence of which is in the transfer and development of pre-recorded knowledge, skills, and competencies that ensure successful professional 
activities, and the use of an organizational and management approach in learning becomes part of the human resource management process.

The transformations of the modern world are due to the change of leading paradigms. It is generally accepted interpretation, according to which the paradigm is interpreted as "a set of theoretical and methodological provisions adopted by the scientific community at a certain stage in the development of science and used as a model, standard for scientific research, interpretation, evaluation, and systematization of scientific data, for understanding hypotheses and solving tasks arising in the process of scientific knowledge" [10]. As a result of such transformations, there are changes in the methodological foundations of any science, including pedagogy.

Thus, the idea of professionalism in the activity of a teacher is considered by N. V. Kuzmina and A. M. Rean [12], according to whom professionalism in activity as a qualitative characteristic of a subject of activity is a representative of this profession, which is determined by the measure of possessing the modern content and modern means of solving professional tasks, productive ways of its implementation.

Achieving these competency increments (a certain level of professionalism), the teachers are provided largely for additional professional education. In accordance with Article 76 of the Federal Law of December 29, 2012 No. 273-FZ (as amended on 07.03.2018) "On Education in the Russian Federation," additional professional education "is aimed at meeting educational and professional needs, professional development of a person, ensuring his compliance qualification of the changing conditions of professional and social environment". Thus, additional professional pedagogical education should be restructured in accordance with the current innovative socio-educational situation, it is necessary to review the approaches to building programs, forms of education, and most importantly the means (technologies) that are mastered and transferred to students in the process of training.

Also, a number of authors note that the system of additional pedagogical education does not fully cope with the tasks of professional development of teachers. It is indicated that the content of advanced training courses is often focused on the transmission of experience, and the result is a complex of knowledge rather than a system of means and ways of professional activity, allowing, among other things, to reflect on one's own experience and build a trajectory of professional growth (Verbitsky, A. A. [13], Vershlovsky, G. S. [14]., Guzeev, V. V. [15], Ananyev, B.G. [16], etc.). Advanced training formats are not aimed at the reflection of professional experience and do not motivate participants to further professional growth and self-development (Serikov, V. V. [17], Bolotov, V. A. [18], etc.). The possibilities of additional professional pedagogical education for solving new social and educational tasks of modern teachers are significantly limited due to a number of objective and subjective factors, including due to the wide and rather variegated palette of unrelated educational services presented in an open Internet space; due to the lack of built-in mechanisms for working with the educational request of consumers of vocational education services; as well as due to modern open educational technologies that are insufficiently described and represented in the APE system, allowing teachers to build a strategy and manage their own professional growth.

Thus, an urgent problem in the system of additional professional education of teachers can be identified: the lack of modern didactic teaching aids, which, based on the cultural experience of students (metasubject, activity, personal), build their trajectory of professional growth in a changing socioeducational situation.

The area of solving the indicated problem is in the development of modern didactic teaching aids for adults, which, based on the principles of individualization and a system-activity approach, actualize and claim the professional experience of students. Examples of modern didactic teaching aids include mapping (including event-resource mapping). [19] The map is one of the means of implementing the idea of sign mediation (according to Vygotsky, L. S.) [20]. The map has an internal and external side of representation, can act as an external reference point (orientation in the external economic, geographical, political, socioeducational, etc. spaces) and as an internal reference point (identification of personal and professional resources, competence deficits for the formation of an individual trajectory of professional growth). 


\section{Conclusion}

The most important component of professional growth for a modern teacher is mastering the methods of reflection of professional experience, methods of its interpretation, strategizing, and on this basis - the formation of an individual trajectory of professional growth.

The pedagogue needs should be able: (i) to design teaching activities (adjusted for changing conditions of reality); (ii) to work in a virtual environment that is rapidly bursting into the learning process; (iii) to orient and use the resources of an open educational space that expands the scope of the educational organization; (iv) to build network communication; (v) to identify and work with the educational interests of students (as a means of motivation); (vi) to track individual achievements of students, building an individual educational program with each and be professionally oriented in a large number of educational offers.

\section{Acknowledgments}

The article was prepared within the framework of the program of policy research on the topic "Conducting a monitoring study of the needs of society (based on citizens' appeals) on the improvement of the general education system" (No. 27.12919.2018/12.1).

\section{References}

[1] Van der Heijden B. et al. (2015). Tailoring professional development for teachers in primary education: The role of age and proactive personality. Journal of Managerial Psychology, 30(1), pp. 22-37.

[2] Kelly, J., \& Cherkowski, S. (2017). Collaboration, collegiality, and collective reflection: A case study of professional development for teachers. Canadian Journal of Educational Administration and Policy, 169.

[3] Kleickmann T. et al. (2016). The effects of expert scaffolding in elementary science professional development on teachers' beliefs and motivations, instructional practices, and student achievement. Journal of Educational Psychology, 108(1), p. 21.

[4] Johnson, K. E., \& Golombek P. R., (2016). Mindful L2 teacher education: A sociocultural perspective on cultivating teachers' professional development. Routledge.

[5] Clarin, M. V. (2015). Innovative Education in Adult Education. Problems of Modern Education, 4, pp. 23-31.

[6] Logvinova, I. M., \& Kopoteva, G. L. (2016). Managing the process of professional development of the head of a general education organization for the implementation of the Federal State Educational Standards of general education. Domestic and foreign pedagogy, 4(31), pp. 123-134.

[7] Zmeyov, S. I. (2015). Adult education and andragogy in the implementation of the concept of continuing education in Russia. Domestic and Foreign Pedagogy, 3(24), pp. 234-243.

[8] Nevzorov, M. N. (2015). The way of educational organization: yesterday and tomorrow. Letters to the Issue. Offline: An Electronic Scientific Journal, 2. pp. 25-25.

[9] Neustroev, S. S. et al. (2015). Strategic development priorities of the Institute of Education Management of the Russian Academy of Education in the context of reforming the academic sector of science: Experience of building a strategy. Education Management: Theory and Practice, 1(17), pp. 324-331.

[10] Kuhn, T. (2017). After the "Structure of Scientific Revolutions". Moscow, Russia: Liters.

[11] Ivanova, S. V. (2015). The didactic concept in the postmodern era. Values and meanings, 3(37), pp. 232-239.

[12] Kuzmina, N.V. (1990). Professionalism of the personality of a teacher and master of industrial training. Moscow, USSR: High school. 
[13] Verbitsky, A. A., \& Rybakina, N. A. (2016). On the system, process, and result of continuing education. Higher education in Russia, 6, pp. 145-154.

[14] Vershlovskyz, S. G. (2013). On the question of the andragogical competence of specialists teaching adults. Lifelong Education: Continuing Education for Sustainable Development, 1(11), pp.277-281.

[15] Guzeev, V. V. (1993). Pedagogical technology: management of teachers' self-education. Director of the School, 1. pp. 28-32.

[16] Ananiev, B. G. (2008). Intellectual development of adults as a characteristic of learning (To the question). Man and Education, 1, pp. 232-239.

[17] Serikov, V. V. (2016). Personal development education as one of the culturological educational models. News of the Volgograd State Pedagogical University, 2(106), pp. 98-107.

[18] Bolotov, V. A. (2014). On the questions about the reform of pedagogical education. Psychological Science and Education, 19, 3, pp. 32-40.

[19] Dovbysh, S. E. (2017). Event-based approach to the teacher's work: The open educational technology "Event-Resource Mapping”. Education Management: Theory and Practice, 4(28), pp.17-29.

[20] Vygotsky, L. S. (1982). A collection of works in 6 volumes (Vol. 2). Moscow.

[21] Neustroev, S. S. et al. (2018). Legal regulation of health restrictions and current law enforcement practices in the organization of training. Journal of History Culture and Art Research, 7(2), pp. 58-71. 